\title{
Maternal High-Fat Diet Promotes the Development and Progression of Prostate Cancer in Transgenic Adenocarcinoma Mouse Prostate Offspring
}

\author{
Tian Yanga,b Xiaobo Wu $u^{a, b}$ Jimeng Hu $u^{a, b}$ Mengbo Hua,b Hua Xua,b \\ Haowen Jiang ${ }^{a, b}$ Qiang Dinga,b \\ aDepartment of Urology, Huashan Hospital, Fudan University, Shanghai, 'Fudan Institute of Urology, \\ Huashan Hospital, Fudan University, Shanghai, China
}

\section{Key Words}

Prostate cancer $\bullet$ Maternal $\bullet$ High fat diet $•$ Cytokines $•$ Akt pathway

\begin{abstract}
Background/Aims: We aim to investigate the impact of maternal high fat diet (HFD) on the development and progression of prostate cancer ( $\mathrm{PCa}$ ) in transgenic adenocarcinoma mouse prostate (TRAMP) offspring. Methods: The TRAMP model was used, and divided into maternal HFD group and normal diet (ND) group in the present study. Each group contained 36 TRAMP mice. Serum levels of leptin, adiponectin, interleukin (IL) $-1 \alpha$, IL-1 $\beta$, IL-6, tumor necrosis factor- $\alpha$ and monocyte chemotactic protein-1 were measured by the 20th, 24th and 28th week old through ProcartaPlex Multiplex Immunoassay. Body fat ratio was measured by MiniQMR. Tumor formation rate was measured through hematoxylin and eosin (H\&E) staining, and mortality rate was measured meantime. Western blot was applied to determine the levels of Protein Kinase B (Akt) and Phosphatase and tensin homolog (PTEN). Results: The mortality rate of maternal HFD group was significantly higher than that of ND group $(P=0.046)$. The tumor formation rate was significantly higher in maternal HFD group than in ND group only in 20th week subgroup $(P=0.040)$. A significant increase of leptin was seen in maternal HFD 20th and 24th week subgroups ( $P=0.001$ and $<0.001$, respectively) and a decrease of adiponectin was seen in maternal HFD 20th and 28th week subgroups ( $P=0.006$ and $<0.001$, respectively). Besides, an activated phos-Akt (P-Akt) and deactivated PTEN were observed in maternal HFD group. Conclusions: Maternal HFD could increase the standard serum leptin level, inhibit the expression of PTEN protein, promote P-Akt protein expression, activate the PI3K/Akt pathway, and ultimately promote the development and progression of PCa in TRAMP offspring.
\end{abstract}




\section{Cellular Physiology Cell Physiol Biochem 2018;47:1862-1870 \\ and Biochemistry Published online: June 29, $2018 \quad \begin{aligned} & \text { DOI: 10.1159/000491066 } \\ & \begin{array}{l}\text { (c) } 2018 \text { The Author(s). Published by S. Karger AG, Basel } \\ \text { www.karger.com/cpb }\end{array}\end{aligned}$}

Yang et al.: Maternal High Fat Diet Promotes Prostate Cancer

\section{Introduction}

Prostate cancer ( $\mathrm{PCa}$ ) is one of the most common malignancies among men worldwide and the second leading cause of death due to the cancer among men in the United States [1]. However, the morbidity and mortality of PCa varies in different countries. Epidemiological studies showed that in Asia, including China, Japan, and Korea, the morbidity and mortality of PCa are lower than those in the United States or Europe [1]. Genetic factors such as genetic polymorphisms in androgen receptor and androgen metabolism pathway enzymes might account for $16 \%-45 \%$ of the risk of PCa [2]. Nevertheless, growing evidence showed that lifestyle and diet also played an important role in the development and progression of PCa. High caloric intake, as well as high-fat diet (HFD), was regarded as a major cause of the increasing morbidity and mortality of PCa, especially advanced PCa [3-5].

Transgenic adenocarcinoma mouse prostate (TRAMP) animal is one of the most widely used mouse model for PCa, which successfully resembles the natural development and progression process of PCa in human [6]. The TRAMP model is generated using the minimal probasin (PB) $-426 /+28$ regulatory sequence to restrict SV40 early gene $(\mathrm{T}$ and $\mathrm{t}$ antigens; Tag) expression in the prostatic epithelium [7]. At the age of 10-12 week, prostatic intraepithelial neoplasia (PIN) and few PCa can be detected in TRAMP mice. Invasive prostate adenocarcinoma began to be detected by $18-20$ weeks of age. By 30-36 weeks of age, almost all TRAMP mice develop PCa, and some might already metastasize to other organs such as lymph nodes, lungs, and bone [8]. Our former research showed TRAMP mouse was a good in vivo model to study the association between HFD and PCa [9-11]. We concluded that HFD could promote the development and progression of PCa in TRAMP mice with elevated proinflammatory cytokines levels. Similar findings were also reported in other researches [12-15].

Although the relationship between HFD and PCa has been widely studied these years, few studies focused on the influence of maternal factors on its offspring. The Fetal Origins of Adult Disease hypothesis assumes that perinatal environmental factors can affect their offspring, increasing the predisposition to certain diseases that might present during adulthood [16]. Several diseases in offspring including obesity, diabetes mellitus, cardiovascular abnormalities, adult schizophrenia and asthma were identified to be associated with maternal obesity during the gestational period [17]. In murine models, maternal perinatal HFD impairs the quality of female gametes and leads to meiotic aneuploidy, embryonic loss, growth retardation, and brain defects in offspring [18]. For example, offspring from obesityprone rat remained obese even if they were fed by normal diet [19]. Female rat fed with HFD would stimulate the proliferation of prostatic glands in its male offspring [20]. To sum up, it seems that a wide variety of embryonic and adult disorders might be programmed by maternal diet.

Maternal obesity or HFD cause alterations in hypothalamus which controls appetite, metabolism and energy expenditure [17]. The most commonly studied hypothalamic appetite regulators are the robust appetite stimulator neuropeptide Y (NPY) and appetite suppressor proopiomelanocortin (POMC). POMC neurons are potent anorectic regulators that suppress appetite by producing $\alpha$-melanocyte-stimulating hormone $(\alpha-\mathrm{MSH})$. In contrast, the NPY neurons act as major orexigenic regulators that stimulate appetite and feeding [21]. Leptin, the adipokine which has multifaceted effects on PCa development [22], is an important cytokine in this programming. Leptin is able to inhibit the NPY neurons and stimulates the activity of the anorexigenic POMC neurons to suppress hunger [23]. Researchers found that the offspring of obese mothers would develop a central leptin resistance in the hypothalamus, resulting in a higher level of serum leptin in the offspring [24]. Besides, recent studies found that maternal HFD activated the Protein Kinase B (Akt) pathway in offspring [17, 20], which was widely recognized as a regulator of cell growth and survival. Phosphatase and tensin homolog (PTEN), the tumor suppressor, also played an important role in this pathway [25]. It then leads to our curiosity about whether maternal HFD has an impact on the PCa of TRAMP offspring and whether Akt pathway is involved in this process. 


\section{Cellular Physiology Cell Physiol Biochem 2018;47:1862-1870 \begin{tabular}{l|l} 
and Biochemistry Published onlIne:June 29, 2018 & $\begin{array}{l}\text { D) } 2018 \text { The Author(s). Published by S. Karger AG, Basel } \\
\text { www.karger.com/cpb }\end{array}$ \\
\hline
\end{tabular} \\ Yang et al.: Maternal High Fat Diet Promotes Prostate Cancer}

In the present study, we applied TRAMP model, and preliminarily measure the serum levels of adipokines including leptin and adiponectin, by using a highly sensitive multiplex suspension array technology kit (FlowCytomix) and flow cytometry. The serum levels of proinflammatory cytokines including interleukin (IL) $-1 \alpha$, IL-1 $\beta$, IL-6, tumor necrosis factor (TNF) $-\alpha$ and monocyte chemotactic protein (MCP)-1 were also measured meantime. The levels of Akt and PTEN were determined by Western blot. We aimed to identify their potential effect in the association between maternal HFD and PCa development and progression in TRAMP offspring.

\section{Materials and Methods}

\section{Animals and Diets}

All animal studies were approved by the Institutional Animal Care and Use Committee from the Huashan Hospital, Fudan University. TRAMP mice (C57BL/6-Tg 8247Ng/J) and C57BL/6 female mice were obtained from Jackson Laboratory (Bar Harbor, Maine, USA). Mice were kept on a 12-hour light/dark cycle with ad libitum access to food and water. TRAMP mice were fed normal diet before they reached the reproductive age. Female mice were divided into two groups, fed with either normal diet or HFD (Table 1) from weaning. Each mouse consumed about 5 grams of food per day in each animal group. Age-matched female mice were mated to age-matched TRAMP mice afterwards. Resulting pups stayed with their mother until weaning. Isolation of mouse-tiptoe DNA and PCR-based screening assay were performed as previously reported [7]. Only TRAMP mice remained and were maintained on normal diet until sacrifice. Each group contained 36 TRAMP mice. Each TRAMP mouse was kept and raised separately to avoid being bitten and attacked by other mice.

\section{Tissue Preparation}

TRAMP mice from both groups were divided into 3 subgroups, which were planned to be euthanized and sampled on the 20th, 24th, and 28th week, respectively, by asphyxiation of $\mathrm{CO}_{2}$. Each subgroup was composed of 12 mice. TRAMP mice were required to fast overnight before sacrifice. The body weight was measured before sampled. Blood was acquired from the portal vein with 1-mL syringe. Blood was centrifuged at 13, $000 \mathrm{rpm}$ for 10 minutes in a refrigerated centrifuge. The serum was transferred to a new eppendorf tube, and kept frozen at $-80^{\circ} \mathrm{C}$ for further study. Mouse prostate was immediately fixed in $10 \%$ buffered formalin for H\&E staining.

\section{Measurement of Body Fat Ratio}

The measurement of body fat ratio of each TRAMP mice was conducted before sacrifice using minispec magnetic resonance analyzer.

\section{Serum Studies}

Concentrations (pg/mL) of leptin, adiponectin, IL- $1 \alpha$, IL-1 $\beta$, IL-6, TNF- $\alpha$ and MCP- 1 in serum were measured by ProcartaPlex Multiplex Immunoassay, using a commercial multiplex suspension array technology kit and flow cytometry. A total of $30 \mu \mathrm{l}$ of serum was examined following manufacturer's instructions. MFI from microspheres was acquired with a BD FACSCanto II and analyzed in FlowCytomix Pro2.2.1 software (eBioscience). Concentration of each analyte was obtained by interpolating fluorescence intensity to a 7-point dilution standard curve supplied by the manufacturer.

\section{Prostate Histology Studies}

Prostate tissues were fixed in $10 \%$ buffered formalin, processed in an alcohol-xylene series, and embedded in paraffin. Sections were cut at $2 \mu \mathrm{m}$ and stained with H\&E. Histological sections were analyzed by pathologists from Department of Pathology, Huashan Hospital,

Table 1. Energy and nutrient composition of diets. ${ }^{\dagger}$ HFD: high fat diet

\begin{tabular}{lcc}
\hline Diet & Normal diet & HFD $^{\dagger}$ \\
\hline Protein(gm \%) & 20 & 22 \\
Fat(gm \%) & 7 & 20 \\
Carbohydrate(gm \%) & 64 & 45 \\
Others(gm \%) & 9 & 13 \\
Energy(Kcal/gm) & 3.99 & 4.48 \\
Protein (\%) & 20 & 20 \\
Fat (\%) & 16 & 40 \\
Carbohydrate (\%) & 64 & 40 \\
\hline
\end{tabular}


Fudan University to distinguish various PCa grades, which was classified as atrophic glands only (no identifiable tumor), PIN and PCa. PIN and PCa were included in the calculation of the tumor formation rate.

\section{Western blot}

All TRAMP mice prostates were excised. Bicinchoninic acid (BCA) assays were used to calculate total protein concentrations. Standard western blotting protocol was followed, with acrylamide gels separated for 3 hours at $30 \mathrm{~mA}$. Blots were blocked in $100 \mathrm{ml} \mathrm{5 \%} \mathrm{non-fat} \mathrm{dry} \mathrm{milk}$ solution for 1 hour at room temperature after transfer. Membranes were incubated in primary antibody overnight at $4^{\circ} \mathrm{C}$. After washed and incubated with secondary antibody for 2 hours, membranes were treated with electronic chemical luminescence (ECL) and imaging. ImageJ was used to quantify the grey value of each band. Data were normalized to actin loading controls and compared afterwards.

\section{Statistical Analysis}

The results were expressed as mean \pm SD. T-test was used for comparison of cytokine levels between the two groups. Fisher exact test or $\chi^{2}$-test was used for comparison of categorical variables, including mortality rate and tumor formation rate. Statistical analysis was performed using IBM SPSS 22.0. Statistical significance was considered as $\mathrm{p}<0.05$.
Table 2. Body weight (g) and fat ratio (\%) of different weeks old TRAMP mice in normal diet group and maternal HFD group. ${ }^{\dagger}$ HFD: high fat diet

\begin{tabular}{lcccc}
\hline & & 20th week $(\mathrm{n}=12)$ & 24th week $(\mathrm{n}=12)$ & 28th week $(\mathrm{n}=12)$ \\
\hline Body Weight (g) & Normal Diet & $20.8 \pm 1.8$ & $25.2 \pm 2.3$ & $28.0 \pm 1.6$ \\
& Maternal HFD & $26.1 \pm 1.1$ & $26.9 \pm 4.1$ & $26.0 \pm 0.8$ \\
P value & & 0.018 & $>0.05$ & $>0.05$ \\
Body Fat Ratio (\%) & Normal Diet & $3.84 \pm 1.2$ & $4.01 \pm 2.1$ & $1.44 \pm 0.36$ \\
& Maternal & & & \\
& HFD $^{\dagger}$ & $5.01 \pm 1.5$ & $6.5 \pm 2.4$ & $0.98 \pm 0.22$ \\
P value & & 0.022 & 0.031 & $>0.05$
\end{tabular}

Table 3. Mortality rate of $\mathrm{TRAMP}^{\dagger}$ mice. ${ }^{\dagger}$ TRAMP: transgenic adenocarcinoma mouse prostate. ${ }^{*} \mathrm{HFD}$ : high fat diet

\begin{tabular}{lccc}
\hline & $\begin{array}{c}\text { Normal diet Group } \\
\mathrm{n}=36\end{array}$ & $\begin{array}{c}\mathrm{HFD}^{\ddagger} \text { group } \\
\mathrm{n}=36\end{array}$ & P value \\
\hline Mortality & & & \\
$\mathrm{n}$ & 2 & 9 & 0.046 \\
$\%$ & 5.55 & 25.00 & \\
\hline
\end{tabular}

Table 4. Pathological results of $\mathrm{TRAMP}^{\dagger}$ mice. TTRAMP: transgenic adenocarcinoma mouse prostate. ${ }^{\ddagger} \mathrm{HFD}$ : high fat diet. §PIN: prostate intraepithelial neoplasia *PCa: prostate cancer

\begin{tabular}{|c|c|c|c|c|}
\hline & atrophic & PIN§ & $\mathrm{PCa}^{*}$ & $P$ value \\
\hline Normal diet 20th week & 9 & 3 & 0 & 0.040 \\
\hline $\begin{array}{l}\text { Maternal HFD } \ddagger 20 \text { th } \\
\text { week }\end{array}$ & 4 & 7 & 1 & \\
\hline Normal diet 24th week & 4 & 5 & 3 & 0.14 \\
\hline Maternal HFD 24th week & 1 & 7 & 4 & \\
\hline Normal diet 28th week & 0 & 5 & 7 & $\mathrm{~N} / \mathrm{A}$ \\
\hline Maternal HFD 28th week & 0 & 3 & 9 & \\
\hline
\end{tabular}

\section{Results}

\section{Body Weight and Fat Ratio}

We observed higher body weights in offspring in maternal HFD 20th week subgroup $(\mathrm{P}=0.018)$ and higher body fat ratio in offspring in maternal HFD 20th week subgroup $(\mathrm{P}=0.022)$ and 24 th week subgroup $(\mathrm{P}=0.031)$. However, the body fat ratio decreased largely in 28th week subgroups in both normal diet and HFD diet TRAMP mice (Table 2). According to the pathological results followed, we suggested that the retarded growth of the HFD offspring might due to the cachexia and fat consumption caused by the progression of PCa.

\section{Mortality Rate and Tumor Formation Rate}

We observed two deaths of TRAMP mice in normal diet group and nine deaths in maternal HFD group. The mortality rate of maternal HFD group was significantly higher than that of normal diet group (Table $3, \mathrm{P}=0.046$ ).

Pathological results were also analyzed. Significantly higher percentage of PIN or PCa was observed in maternal HFD group than in normal diet group in 20th week subgroup (Table 4, $\mathrm{P}=0.04$ ). However, in both 24 th and 28th week subgroups, the results were similar. 
Fig. 1 showed the proliferation of PCa cells in normal and maternal HFD group at 20, 24 and 28 weeks of age, by means of H\&E staining.

\section{Leptin, Adiponectin and Proinflammatory Cytokine Levels in TRAMP Mice Blood}

The results of leptin and adiponectin level in TRAMP mice serum were shown in Fig. 2. Fig. 2(a) displayed leptin levels in TRAMP mice. A significant increase of leptin was seen in maternal HFD group of 20th and 24th week of age ( $P=0.001$ and $<0.001$, respectively). The leptin level of maternal HFD 28th week subgroup was lower than that of 20th and 24th week subgroups.

Fig. 2(b) displayed adiponectin levels in TRAMP mice. A significant decrease of adiponectin was seen in maternal HFD group of 20th and 28th week of age ( $\mathrm{P}=0.006$ and $<0.001$, respectively.). At 24th week of age, TRAMP mice from maternal HFD group also had moderately lower adiponectin than that of TRAMP mice from normal diet group, although without statistical significance $(\mathrm{P}=0.160)$.

No difference was observed on the level of IL $-1 \alpha$, IL-1 $1 \beta$, IL-6, TNF- $\alpha$ or MCP-1 between normal diet group and maternal HFD group.

\section{Total Akt, phos-Akt (P-Akt) and PTEN}

\section{Levels in Prostate Tissue}

The protein level of Akt, P-Akt and PTEN in the prostate from offspring was investigated by western blot. As shown in Fig. 3, we observed an increase in P-Akt level and a decrease in PTEN level between normal diet group and maternal HFD group. However, the level of Akt was similar between two groups.

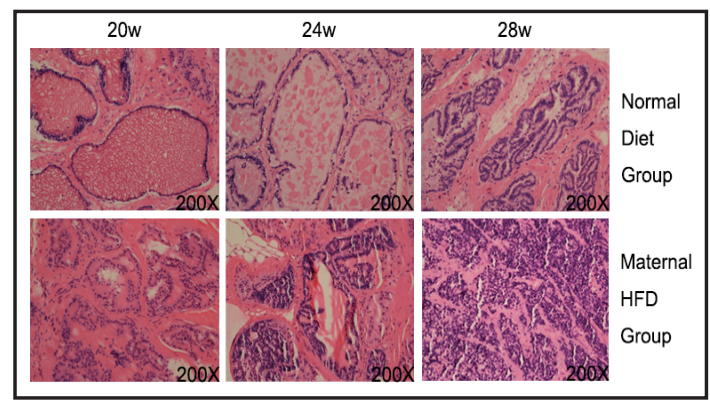

Fig. 1. $\mathrm{H} \& \mathrm{E}$ staining of prostate acini from normal diet and maternal HFD-exposed offspring at 20, 24 and 28 weeks of age.

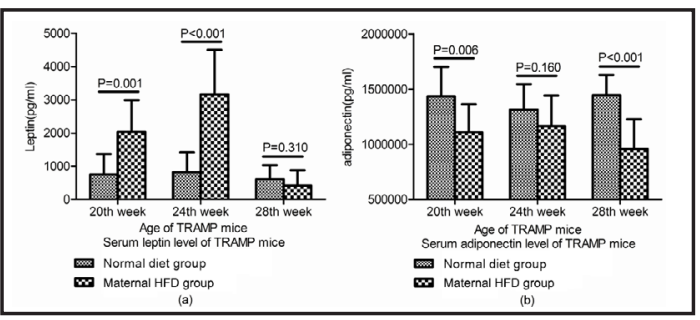

Fig. 2. Cytokines levels in TRAMP mice. Two-sample t-test was used for comparison of cytokine levels between normal diet group and maternal HFD group. (a) Serum leptin level in TRAMP mice. (b) Serum adiponectin level in TRAMP mice.
Fig. 3. Western blot analysis (a) of prostate total Akt, P-Akt and PTEN and gery value ratio (grey value of target protein normalized to actin loading control of prostate total Akt (b), P-Akt (c) and PTEN (d) in TRAMP mice at different weeks of age, $n=6$ mice per condition.

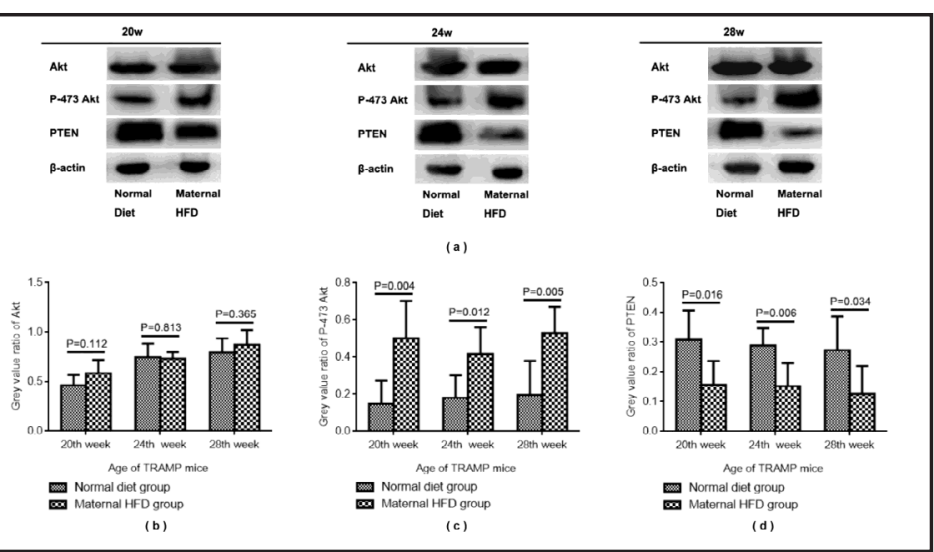




\section{Cellular Physiology Cell Physiol Biochem 2018;47:1862-1870 \\ \begin{tabular}{l|l} 
DOI: 10.1159/000491066 & and Biochemistry 2018 The Author(s). Published by S. Karger AG, Basel \\
Published online: June 29, 2018 & $\begin{array}{l}\text { www.karger.com/cpb } \\
\text { and }\end{array}$
\end{tabular} \\ Yang et al.: Maternal High Fat Diet Promotes Prostate Cancer}

\section{Discussion}

In the present study, we identified a novel risk factor for PCa: maternal HFD. To our knowledge, this is the first study to apply maternal HFD model on TRAMP mice. Our study revealed that the TRAMP offspring of HFD-fed mice sufferred higher tumor formation rate and mortality rate, along with a higher level of leptin and lower level of adiponectin. An obvious increase in mortality rate of maternal HFD group was identified, indicating that maternal HFD might promote PCa progression and lead to poorer prognosis in the offspring. Besides, an earlier tumor formation was also discovered, which implied that maternal HFD might promote PCa development.

Leptin is a versatile $16 \mathrm{kDa}$ polypeptide encoded by the obese (Ob) gene [26]. Leptin is mainly produced in adipose tissues, and also synthesized in other organs and tissues such as stomach, skeletal muscles and mammary epithelium. Long-term exposure to leptin was shown to enhance the growth of three main PCa cell lines (LNCaP, DU145 and PC-3) [27]. Leptin also induces the expression of transforming growth factor $\beta 1$, basic fibroblast growth factor, and vascular endothelial growth factor (VEGF) in DU145 and PC-3 cells, stimulating cell survival pathways and leading to angiogenesis and proliferation [28]. Stattin et al. showed that leptin receptor could be detected in normal, high-grade PIN lesions and malignant prostatic epithelium. Besides, moderately elevated plasma leptin concentrations are associated with later development of PCa [29]. Chang also reported that leptin may affect the risk of clinically relevant PCa through testosterone and factors related to stature and obesity [30]. Consistently, we found an increase of serum leptin level in both maternal HFD 20th and 24th week subgroups, as compared with normal diet group. In maternal HFD 28th week subgroup, the leptin level was lower than that in maternal HFD 20th and 24th week subgroups. This trend of leptin level was consistent with the alterations in the level of body fat ratio in TRAMP mice. Therefore, we speculated that the decrease of serum leptin in 28th week might due to the constant consumption of adipose tissues in the advanced stage of PCa. The outcome also proved that maternal HFD might promote PCa progression from another perspective.

Adiponectin was found lower in maternal HFD groups in the present study. Adiponectin, a protein produced by adipocytes, was firstly discovered by Scherer in 1995. Various investigations were carried afterwards, showing the direct anti-diabetic, anti-atherogenic and anti-inflammatory properties of adiponectin [31,32]. Besides, circulating adiponectin levels are lower in several malignancies, including PCa. A meta-analysis concerning the role of circulating adiponectin in PCa found that concentration of adiponectin in cancer patients was significantly lower than in controls. A decreased concentration of adiponectin was associated with a significantly greater risk of PCa [33]. Bub et al. showed that adiponectin was a growth inhibitor in PCa cells [34]. Further findings indicated that endogenous adiponectin functioned as a tumor suppressor through inhibiting epithelial-to-mesenchymal transition of PCa cells [35]. On the other side, some researchers presented negative results, suggesting that adiponectin may not play an important role in promoting clinically aggressive PCa $[36,37]$. As mentioned before, the consumption of adipose tissues in advanced PCa, rather than tumor itself, might also cause the decrease of adiponectin. Therefore, it was difficult to make a distinction of these two factors in the clinical trials, which might result in different outcomes in various studies. Further investigations are required to reveal the relationship between adiponectin and PCa.

The phosphatidylinositol 3-kinase (PI3K)/Akt pathway is a major signaling downstream of growth factor receptor tyrosine kinases [38]. The activation of this pathway is critical to the aggressiveness of PCa [25]. In a classical Akt pathway, PI3K is stimulated and convert phosphatidylinositol 4, 5-bisphosphate (PIP2) to phosphatidylinositol $(3,4,5)$-triphosphate (PIP3). Akt, which binds to PIP3, is then activated through phosphorylation [39]. On the contrary, PTEN converts PIP3 to PIP2, therefore antagonizing PI3K and inhibiting Akt pathway [25]. Consistently, we observed an increased level of P-Akt and a decreased level of PTEN in maternal HFD group, which indicated that maternal HFD might activate PI3K/ 
Akt pathway in the offspring, and promoted the development and progression of PCa. It was reported that both leptin and adiponectin participated in PI3K/Akt pathway in different malignancies $[40,41]$. However, few studies mentioned these two cytokines with PI3K/Akt pathway in PCa. Our research might provide a novel strategy towards the prevention and treatment of PCa.

Several limitations existed in the present study. First, female mice were fed with HFD in their whole life. We didn't solely focus on the gestational period of female mice, from pregnancy to lactation period. Neither did we set subgroups fro these two separated periods. Further researches are warranted to distinguish the role of them in the PCa offspring. Second, the limited significance of adiponectin level in 24th week subgroup might due to the relatively small sample size. Third, the relationship between leptin, adiponectin and PI3k/ Akt pathway was not fully revealed in the study. Investigations on cell biology are needed in the future.

In conclusion, our study indicated that maternal HFD could increase the standard serum leptin level, inhibit the expression of PTEN protein, promote P-Akt protein expression, activate the PI3K / Akt pathway, and ultimately promoted the development and progression of PCa in TRAMP offspring.

\section{Abbreviations}

HFD (high fat diet); TRAMP (transgenic adenocarcinoma mouse prostate); PCa (prostate cancer ); $\alpha$-MSH ( $\alpha$-melanocyte-stimulating hormone); TNF (tumor necrosis factor); MCP (monocyte chemotactic protein); H\&E (hematoxylin and eosin); Akt (Protein Kinase B); PTEN (Phosphatase and tensin homolog ); PIN (prostatic intraepithelial neoplasia); NPY (neuropeptide Y ); POMC (proopiomelanocortin); IL (interleukin ); VEGF (vascular endothelial growth factor); BCA (bicinchoninic acid); ECL (electronic chemical luminescence); P-Akt (phos-Akt); PI3K (phosphatidylinositol 3-kinase); PIP2 (phosphatidylinositol 4, 5-bisphosphate ); PIP3 (phosphatidylinositol (3, 4,5)-triphosphate).

\section{Acknowledgements}

We appreciated all the contributions from study participants, coordinators and urologists. We thank Liu Kai (JIA YUAN biological company) for his technical assistance.

The study was supported by National Science Foundation of China (81272835) and Shanghai Sailing Program (17YF1401700). The funders had no role in study design, data collection and analysis, decision to publish or preparation of the manuscript.

All applicable international, national, and/or institutional guidelines for the care and use of animals were followed.

Yang Tian: Project development, Experiment performing, Data analysis, Manuscript writing; Wu Xiaobo: Project development, Experiment performing, Data analysis, Manuscript writing; Hu Jimeng: Project development, Experiment performing, Data collection; Hu Mengbo: Data analysis, Manuscript writing, Acquisition of funding; Xu Hua: Data collection, Manuscript writing; Jiang Haowen: Project development, Manuscript Revision, Acquisition of funding. Ding Qiang: Manuscript Revision. All authors reviewed and approved the manuscript.

\section{Disclosure Statement}

The authors declare to have no competing interests. 


\section{Cellular Physiology Cell Physiol Biochem 2018;47:1862-1870

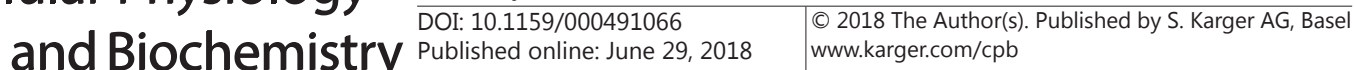

Yang et al.: Maternal High Fat Diet Promotes Prostate Cancer

\section{References}

1 Siegel RL, Miller KD, Jemal A: Cancer statistics, 2016 CA Cancer J Clin 2016;66:7.

- Baker SG, Lichtenstein P, Kaprio J, Holm N: Genetic Susceptibility to Prostate, Breast, and Colorectal Cancer among Nordic Twins. Biometrics 2005;61:55-63.

3 Kristal AR, Cohen JH, Qu P, Stanford JL: Associations of energy, fat, calcium, and vitamin D with prostate cancer risk. Cancer Epidemiol Biomarkers Prev 2002;11:719-725.

-4 Fleshner N, Bagnell PS, Klotz L, Venkateswaran V: Dietary fat and prostate cancer. J Urol 2004;171:S19-24.

5 Lophatananon A, Archer J, Easton D, Pocock R, Dearnaley D, Guy M, Kote-Jarai Z, O’Brien L, Wilkinson RA, Hall AL, Sawyer E, Page E, Liu JF, Barratt S, Rahman AA, UK Genetic Prostate Cancer Study Collaborators, British Association of Urological Surgeons' Section of Oncology, Eeles R, Muir K: Dietary fat and early-onset prostate cancer risk. Br J Nutr 2010;103:1375-1380. Bodmer WF: Prostate cancer 2000. Prostate Cancer Prostatic Dis 2001;3:218-223.

Greenberg NM, Demayo F, Finegold MJ, Medina D, Tilley WD, Aspinall JO, Cunha GR, Donjacour AA, Matusik RJ, Rosen JM: Prostate cancer in a transgenic mouse. Proc Natl Acad Sci U S A 1995;92:3439-23443.

8 Gingrich JR, Barrios RJ, Morton RA, Boyce BF, DeMayo FJ, Finegold MJ, Angelopoulou R, Rosen JM, Greenberg NM: Metastatic Prostate Cancer in a Transgenic Mouse. Cancer Res 1996;56:4096-4102.

-9 Hua X, Mengbo H, Peide B, Wenhui Z, Qiang D, Haowen J: Will metformin postpone high-fat diet promotion of TRAMP mouse prostate cancer development and progression? Int Urol Nephrol 2014;46:2327-2334.

10 Hua X, Haowen J, Qiang D: Insulin-Like growth factor 1 related pathways and high-fat diet promotion of transgenic adenocarcinoma mouse prostate (TRAMP) cancer progression. Actas Urol Esp 2015;39:161-168.

-11 Xu H, Hu MB, Bai PD, Zhu WH, Liu SH, Hou JY, Xiong ZQ Ding Q Jiang HW: Proinflammatory Cytokines in Prostate Cancer Development and Progression Promoted by High-Fat Diet. Biomed Res Int 2015;2015:1-7.

-12 Llaverias G, Danilo C, Wang Y, Witkiewicz AK, Daumer K, Lisanti MP, Frank PG: A Western-type diet accelerates tumor progression in an autochthonous mouse model of prostate cancer. Am J Pathol 2010;177:3180-3191.

$\longrightarrow 13$ Bonorden MJ, Grossmann ME, Ewing SA, Rogozina OP, Ray A, Nkhata KJ, Liao DJ, Grande JP, Cleary MP: Growth and Progression of TRAMP Prostate Tumors in Relationship to Diet and Obesity. Prostate Cancer 2012;2012:543970.

14 Park SH, Chang SN, Baek MW, Kim DJ, Na YR, Seok SH, Lee BH, Kim KS, Park JH: Effects of dietary high fat on prostate intraepithelial neoplasia in TRAMP mice. Lab Anim Res 2013;29:39-47.

15 Chang SN, Han J, Abdelkader TS, Kim TH, Lee JM, Song J, Kim KS, Park JH, Park JH: High animal fat intake enhances prostate cancer progression and reduces glutathione peroxidase 3 expression in early stages of TRAMP mice. Prostate 2014;74:1266-1277.

16 Skogen JC, Overland S: The fetal origins of adult disease: a narrative review of the epidemiological literature. JRSM Short Rep 2012;3:59.

17 Daniel D, Mcauliffe FM: The Molecular Mechanisms of Offspring Effects from Obese Pregnancy. Obes Facts 2013;6:134-145.

18 Luzzo KM, Wang Q, Purcell SH, Chi M, Jimenez PT, Grindler N, Schedl T, Moley KH: High fat diet induced developmental defects in the mouse: oocyte meiotic aneuploidy and fetal growth retardation/brain defects. PLoS One 2012;7:e49217.

-19 Gorski JN, Dunn-Meynell AA, Hartman TG, Levin BE: Postnatal environment overrides genetic and prenatal factors influencing offspring obesity and insulin resistance. Am J Physiol Regul Integr Comp Physiol 2006;291:R768-678.

-20 Benesh EC, Humphrey PA, Wang Q, Moley KH: Maternal high-fat diet induces hyperproliferation and alters Pten/Akt signaling in prostates of offspring. Sci Rep 2013;3:3466.

21 Bouret SG, Simerly RB: Developmental programming of hypothalamic feeding circuits. Clin Genet 2006;70:295-301.

-22 Alshaker H, Sacco K, Alfraidi A, Muhammad A, Winkler M, Pchejetski D: Leptin signalling, obesity and prostate cancer: molecular and clinical perspective on the old dilemma. Oncotarget 2015;6:35556-3563.

23 Djiane J, Attig L: Role of leptin during perinatal metabolic programming and obesity. J Physiol Pharmacol 2008;59:S55-63.

24 Kirk SL, Samuelsson AM, Argenton M, Dhonye H, Kalamatianos T, Poston L, Taylor PD, Coen CW: Maternal obesity induced by diet in rats permanently influences central processes regulating food intake in offspring. PLoS One 2009;4:e5870. 


\section{Cellular Physiology Cell Physiol Biochem 2018;47:1862-1870

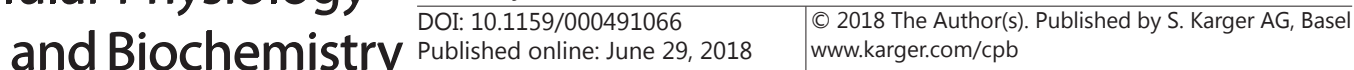

25 Song MS, Salmena L, Pandolfi PP: The functions and regulation of the PTEN tumour suppressor. Nat Rev Mol Cell Biol 2012;13:283-296.

-26 Zhang Y, Proenca R, Maffei M, Barone M, Leopold L, Friedman JM: Positional cloning of the mouse obese gene and its human homologue. Nature 1994;372:425-432.

-27 Noda T, Kikugawa T, Tanji N, Miura N, Asai S, Higashiyama S, Yokoyama M: Long-term exposure to leptin enhances the growth of prostate cancer cells. Int J Oncol 2015;46:1535-1542.

-28 Frankenberry KA, Somasundar P, McFadden DW, Vona-Davis LC: Leptin induces cell migration and the expression of growth factors in human prostate cancer cells. Am J Surg 2004;188:560-565.

-29 Stattin P, Söderberg S, Hallmans G, Bylund A, Kaaks R, Stenman UH, Bergh A, Olsson T: Leptin is associated with increased prostate cancer risk: a nested case-referent study. J Clin Endocrinol Metab 2001;86:13411345.

-30 Chang S, Hursting SD, Contois JH, Strom SS, Yamamura Y, Babaian RJ, Troncoso P, Scardino PS, Wheeler TM, Amos CI, Spitz MR: Leptin and prostate cancer. Prostate 2001;46:62-67.

-31 Ouchi N, Kihara S, Funahashi T, Nakamura T, Nishida M, Kumada M, Okamoto Y, Ohashi K, Nagaretani H, Kishida K, Nishizawa H, Maeda N, Kobayashi H, Hiraoka H, Matsuzawa Y: Reciprocal association of C-reactive protein with adiponectin in blood stream and adipose tissue. Circulation 2003;107:671-674.

-32 Bråkenhielm E, Veitonmäki N, Cao R, Kihara S, Matsuzawa Y, Zhivotovsky B, Funahashi T, Cao Y: Adiponectininduced antiangiogenesis and antitumor activity involve caspase-mediated endothelial cell apoptosis. Proc Natl Acad Sci U S A 2004;101:2476-2481.

33 Liao Q, Long C, Deng Z, Bi X, Hu J: The role of circulating adiponectin in prostate cancer: a meta-analysis. Int J Biol Markers 2015;30:22-31.

34 Bub JD, Miyazaki T, Iwamoto Y: Adiponectin as a growth inhibitor in prostate cancer cells. Biochem Biophys Res Commun 2006;340:1158-1166.

-35 Tan W, Wang L, Ma Q Qi M, Lu N, Zhang L, Han B: Adiponectin as a potential tumor suppressor inhibiting epithelial-to-mesenchymal transition but frequently silenced in prostate cancer by promoter methylation. Prostate 2015;75:1197-1205.

-36 Stevens VL, Jacobs EJ, Sun J, Gapstur SM: No association of plasma levels of adiponectin and c-peptide with risk of aggressive prostate cancer in the Cancer Prevention Study II Nutrition Cohort. Cancer Epidemiol Biomarkers Prev 2014;23:890-892.

-37 Medina EA, Shi X, Grayson MH, Ankerst DP, Livi CB, Medina MV, Thompson IM Jr, Leach RJ: The Diagnostic Value of Adiponectin Multimers in Healthy Men Undergoing Screening for Prostate Cancer. Cancer Epidemiol Biomarkers Prev 2014;23:309-315.

38 Hopkins BD, Hodakoski C, Barrows D, Mense SM, Parsons RE: PTEN function: the long and the short of it. Trends Biochem Sci 2014;39:183-190.

-39 Hemmings BA, Restuccia DF: PI3K-PKB/Akt Pathway. Cold Spring Harb Perspect Biol 2012;4:a011189.

40 El-Masry OS, Kaltoom AS, Brown BL, Dobson PRM: Differential crosstalk between the AMPK and PI3K/Akt pathways in breast cancer cells of differing genotypes: Leptin inhibits the effectiveness of AMPK activation. Oncol Rep 2015;34:1675-1680.

41 Lee HP, Lin CY, Shih JS, Fong YC, Wang SW, Li TM, Tang CH: Adiponectin promotes VEGF-A-dependent angiogenesis in human chondrosarcoma through PI3K, Akt, mTOR, and HIF- $\alpha$ pathway. Oncotarget 2015;6:36746-3661. 